\title{
6

\section{Modified Endoscopic Ultrasound Needle to Obtain Histological Core Tissue Samples: A Retrospective Analysis}

\author{
Munish Ashat ${ }^{1}$, Kaartik Soota ${ }^{2}$, Jagpal S. Klair ${ }^{3}$, Sarika Gupta ${ }^{4}$, Chris Jensen ${ }^{4}$, Arvind R. Murali', Randhir Jesudoss' ${ }^{1}$, \\ Rami El-Abiad' ${ }^{1}$ and Henning Gerke' \\ ${ }^{1}$ Department of Gastroenterology and Hepatology, University of lowa Hospitals and Clinics, lowa City, IA, ${ }^{2}$ Department of Gastroenterology \\ and Hepatology, the University of Alabama at Birmingham, Birmingham, AL, ${ }^{3}$ Digestive Disease Institute, Virginia Mason Medical Center, \\ Seattle, WA, ${ }^{4}$ Department of Pathology, University of lowa Hospitals and Clinics, lowa City, IA, USA
}

Background/Aims: Endoscopic ultrasound (EUS)-guided fine-needle aspiration is very effective for providing specimens for cytological evaluation. However, the ability to provide sufficient tissue for histological evaluation has been challenging due to the technical limitations of dedicated core biopsy needles. Recently, a modified EUS needle has been introduced to obtain tissue core samples for histological analysis. We aimed to determine (1) its ability to obtain specimens for histological assessment and (2) the diagnostic accuracy of EUS-guided fine-needle biopsy (EUS-FNB) using this needle.

Methods: We retrospectively analyzed consecutive cases of FNB using modified EUS needles for 342 lesions in 303 patients. The cytology and histological specimens were analyzed. Diagnostic accuracy was calculated.

Results: Adequate cytological and histological assessment was possible in 293/342 (86\%) and 264/342 (77\%) lesions, respectively. Diagnostic accuracy of the cytological specimen was 294/342 (86\%) versus $254 / 342$ (74\%) for the histological specimen ( $p<0.01$ ). Diagnostic accuracy of the combined cytological and histological assessment was 323/342 (94.4\%), which was significantly higher than that of both histology alone $(p<0.001)$ and cytology alone $(p=0.001)$.

Conclusions: EUS-FNB with the modified EUS needle provided histologic tissue cores in the majority of cases and achieved excellent diagnostic accuracy with few needle passes. Clin Endosc 2020;53:471-479

Key Words: Diagnostic accuracy; Endoscopic ultrasound; Fine-needle biopsy; Tissue yield

\section{INTRODUCTION}

Endoscopic ultrasound-guided fine needle aspiration (EUS-FNA) has been established as an effective technique for sampling tissue inside and around the gastrointestinal (GI) tract, including the pancreas, liver, lymph nodes, and adrenal glands. EUS-FNA is a convenient, minimally invasive, and

Received: June 4, 2019 Revised: August 21, 2019

Accepted: August 26, 2019

Correspondence: Jagpal S. Klair

Digestive Disease Institute, Virginia Mason Medical Center, 1100 9th Ave, Seattle, WA 98101 , USA

Tel: +1-319-356-4901, Fax: +1-319-384-8559, E-mail: KlairJagpals@gmail.com ORCID: https://orcid.org/0000-0003-4345-2851

cc This is an Open Access article distributed under the terms of the Creative Commons Attribution Non-Commercial License (http://creativecommons.org/ licenses/by-nc/3.0) which permits unrestricted non-commercial use, distribution, and reproduction in any medium, provided the original work is properly cited. safe procedure with an estimated sensitivity of $85 \%-95 \%$ and specificity of $95 \%-98 \%$ and a diagnostic accuracy ranging from $78 \%$ to $95 \% .{ }^{1,2}$ However, the actual diagnostic yield of EUS-FNA will depend on the site and size of the lesion. Lack of Rapid On-Site Cytological assessment (ROSE), ${ }^{3,4}$ blood contamination in aspirates from vascular lesions, and limited cellularity in tumors with a significant desmoplastic reaction decrease the overall diagnostic accuracy. ${ }^{5-7}$ Furthermore, cytological specimens alone may not allow for the accurate sub-classification of lymphomas. Additionally, accessory stains for the subclassification of GI spindle cell tumors and characterization of malignancies that require larger samples may be difficult to obtain with the cytologic material alone. ${ }^{8}$ Diagnostic difficulties may also arise with well-differentiated tumors that require a high-quality cellular sample. Finally, histological tissue samples have been found to be superior to cytologic samples in the diagnosis of benign disease. ${ }^{3,49}$ To circumvent 
these problems, various needles used to obtain histological samples were developed. ${ }^{10}$

The EUS-Trucut needle (Cook Medical, Limerick, Ireland) contained a spring-loaded mechanism similar to percutaneous Trucut needles. Although histological samples could successfully be obtained with this needle design, it was prone to failure if the biopsy target required angulated endoscope positions, especially in trans-duodenal biopsies. This prevented the widespread use of this needle, which is no longer commercially available. More recently, new needle designs (Procore [Wilson-Cook Medical Inc., Winston-Salem, NC, USA], SharkCore [Medtronic, Dublin, Ireland], Acquire [Boston Scientific, Natick, MA, USA]) have been introduced with modified tips. These can be used with the same ease as conventional FNA needle. Data on the performance of these needles are still limited.

We conducted a retrospective study analyzing the yield of histologic samples and the diagnostic accuracy of EUS-guided fine-needle biopsy (EUS-FNB) using the SharkCore (SC) needle (Medtronic Co., Boston, MA, USA).

\section{MATERIALS AND METHODS}

\section{Patients}

A retrospective cohort study was conducted to analyze patients who underwent tissue sampling using the SC EUS-FNB needle between January 2012 and April 2017. The procedures were done at a tertiary care medical center with available ROSE facilities. We included any patient aged $>18$ years who received EUS-guided FNA/FNB using the SC needle for solid lesions within or in proximity to the GI tract. We excluded patients who had EUS-FNA for cystic fluid aspiration, pregnant females, patients aged $\leq 18$ years, patients with international normalized ratio $>1.5$ and platelet count $<50,000$, and medically unstable patients.

\section{Study device}

The SC needle is made of stainless steel and contains a nitinol stylet. The device has a multifaceted opposite bevel tip incorporating 2 sharp points of different lengths (Fig. 1).

\section{Endoscopic ultrasound sampling procedure}

All EUS-FNB procedures were performed in the standard manner using linear echoendoscopes (GF-UC140P, GFUCT140, GF-UCT180; Olympus America Inc., Center Valley, PA, USA). All EUS-FNB procedures were performed by 1 of 2 experienced endosonographers (REA and HG). Once the site was identified, the lesion was punctured using either a $19 \mathrm{G}$, $22 \mathrm{G}$, or $25 \mathrm{G}$ needle at the discretion of the endoscopist. The stylet was then slowly retracted while the needle was moved back and forth within the target lesion.

\section{Specimen preparation and assessment}

After withdrawal of the needle, the needle content was expressed onto a slide by advancing the stylet. Using small needles or toothpicks, visible tissue cores were separated from blood and touched onto a second slide for touch imprint preparations ("touch preps") before being placed in formalin, embedded into paraffin, and sectioned for standard hematoxylin and eosin staining as per the standard pathology protocol. If no or scant visible tissue cores were present, the sediments were used for smears and/or placed in cell block medium. ROSE was used in most cases using the Diff-Quik method. A specialized GI cytopathologist evaluated the specimen slides.

\section{Outcome measures}

\section{Specimen quality}

Cytological specimens (touch imprint cytology and smears) and histological specimens (cell block and tissue in formalin) were reviewed by a pathologist for cytological and histological adequacy.

A scoring system was used for the cytological assessment (score of 0 - no material, 1 - limited cytological interpretation, 2 - adequate cytological assessment) and the histological assessment (0 - no material, 1 - limited histological interpretation, 2 - adequate histological interpretation with low quality, 3 - adequate histological interpretation with high quality). Adequate histologic specimens were defined as samples with a histology score of 2 or 3 .

\section{Diagnostic accuracy}

Since false positive results for neoplastic lesions on histological and cytological evaluation are rare, we considered a

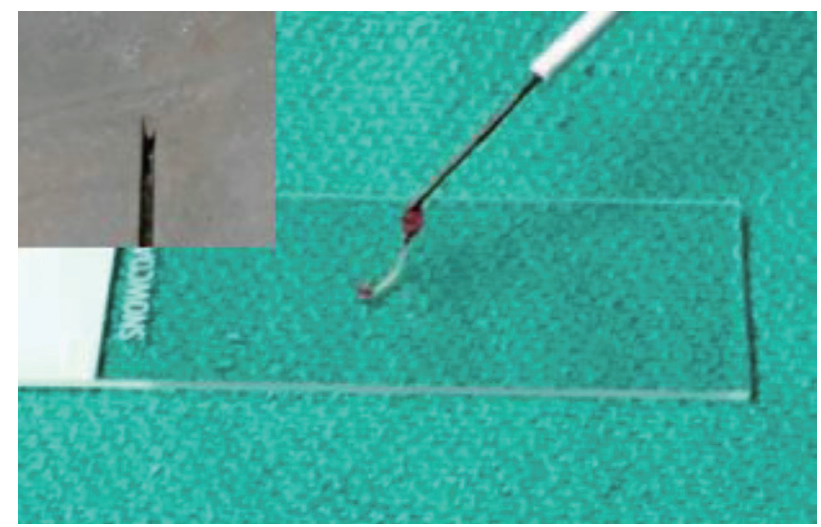

Fig. 1. SharkCore needle (Medtronic Co., Boston, MA, USA) and the core sample. 
cytological or histological diagnosis of malignancy as a true positive. ${ }^{11-13}$ The criterion for diagnosing benign diagnosis, who did not underwent surgical resection was based on clinical impression, imaging characteristics and clinical course. If the benign diagnosis was consistent with clinical impression we considered this as true positive. Specific benign diagnoses, such as granulomatous lymphadenopathies, were generally considered diagnostic. Non-specific benign diagnoses including normal parenchymal tissue were considered non-diagnostic unless follow-up supported a particular clinical diagnosis. ${ }^{14}$

\section{Statistical analysis}

Median and range or interquartile range (IQR) were used to report the histology score, cytology score, and number of needle passes. Two-tailed $p$-values were calculated using Fisher's exact test for categorical data; $p$-values of $<0.05$ were considered statistically significant.

\section{RESULTS}

During the study period, EUS-FNB using the SC needle was performed on 342 solid lesions in 303 patients (mean age, $64 \pm 13.1$ years; M/F, 199/104). Biopsy targets were pancreatic lesions $(n=153,45 \%)$ (91 pancreatic head lesions [26.6\%], 62 pancreatic body/tail lesions [18\%]), liver lesions $(n=22$, $6.4 \%)$, lymph nodes ( $n=117,34 \%)$ (57 mediastinal lesions [16.6\%], 60 abdominal/retroperitoneal lymph nodes [17.5\%]), subepithelial lesions ( $n=27,7.8 \%)$, adrenal gland lesions $(n=10$, $2.9 \%)$, and other lesions $(n=13,3.8 \%)$, including ampullary mass, pelvic/rectal lesions, and splenic lesions (Table 1). The median diameter of the lesions on EUS was $25 \mathrm{~mm}$ (range, 6-110 mm). A $22 \mathrm{G}$ needle was used in 236 cases, a $25 \mathrm{G}$ was used in 105 cases, and a $19 \mathrm{G}$ was used in 7 cases. Both $22 \mathrm{G}$ and $25 \mathrm{G}$ needles were used in 6 patients. The median number of passes per lesion was 2 (IQR, 2-3).

\section{Specimen quality}

The median histology score was 3 (range, $0-3$; see above) and the median cytology score was 2 (range, $0-2$; see above). Specimens that enabled adequate histologic assessment (histology score $\geq 2$ ) were obtained in $77.1 \%$ (264/342) of patients compared to $85.6 \%(293 / 342)$ of patients with adequate cytological samples (cytology score 2; Table 2).

\section{Diagnostic accuracy}

Cytological analysis yielded a higher diagnostic accuracy compared to histologic analysis, at $86 \%$ (294/342) of lesions vs. $74.2 \%(254 / 342)$, respectively $(p<0.01)$. A limited cytological specimen (cytology score 1) yielded a diagnosis in 1 patient, thus making the diagnostic accuracy of cytology higher than the percentage of adequate cytologic specimens. The diagnostic accuracy of combined histologic and cytologic assessment $(323 / 342,94.4 \%)$ was higher than that of either cytology or histology alone ( $p<0.01$ for both; Table 3 ).

A total of 58 patients had a non-neoplastic diagnosis and did not undergo surgical resection (Table 4). These patients were all followed for at least 12 months. A diagnosis was then made based on a specific benign entity and/or a combination of clinical impression, imaging characteristics, and a clinical course.

Nineteen patients had a non-specific diagnosis after the initial EUS-FNB (Table 5). In 1 patient with chronic pancreatitis, the biopsy was taken from a pancreatic head mass with

Table 1. Demographics, Lesions, and the SharkCore Needle Description

\begin{tabular}{|c|c|}
\hline Age, yr & $64.8 \pm 13.1$ \\
\hline Sex (Male, $n)$ & $199(65.7 \%)$ \\
\hline Size of mass on EUS, mm-median (range) & $25(6-110)$ \\
\hline \multicolumn{2}{|l|}{ Diagnosis } \\
\hline Neoplastic & $265(77.4 \%)$ \\
\hline Non-neoplastic & $58(16.9 \%)$ \\
\hline Uncertain & $19(5.5 \%)$ \\
\hline Lesion location & $n=342$ \\
\hline Pancreatic head and uncinate & 91 \\
\hline Pancreatic body and tail & 62 \\
\hline Liver & 22 \\
\hline Mediastinal mass & 57 \\
\hline $\begin{array}{l}\text { Abdominal and retroperitoneal } \\
\text { lymphadenopathy }\end{array}$ & 60 \\
\hline Adrenal gland & 10 \\
\hline Subepithelial lesions & 27 \\
\hline Others & 13 \\
\hline \multicolumn{2}{|l|}{ Needle used } \\
\hline $19 \mathrm{G}$ & 7 \\
\hline $22 \mathrm{G}$ & $236^{\text {a) }}$ \\
\hline $25 \mathrm{G}$ & $105^{\text {a) }}$ \\
\hline \multicolumn{2}{|l|}{ Route } \\
\hline Trans-esophageal & 56 \\
\hline Trans-gastric & $165^{\mathrm{b})}$ \\
\hline Trans-duodenal & $121^{\mathrm{b})}$ \\
\hline Trans-rectal & 4 \\
\hline Trans-colonic & 1 \\
\hline
\end{tabular}

EUS, endoscopic ultrasound.

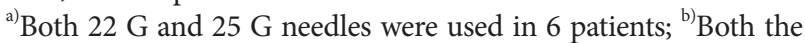
transgastric and transduodenal approaches were used in 5 patients. 
Table 2. Detailed Analysis of Specimen Quality Evaluation

\begin{tabular}{lc}
\hline All patients $(n=342)$ & \\
Histology score & Number of patients $(n=342)$ \\
0 & $46(13.4 \%)$ \\
1 & $32(9.3 \%)$ \\
2 & $76(22.2 \%)$ \\
3 & $188(54.9 \%)$ \\
Cytology score & \\
0 & $6(1.7 \%)$ \\
1 & $43(12.5 \%)$ \\
2 & $293(85.6 \%)$
\end{tabular}

For patients with pancreatic lesions only

Histology score

$0 \quad 23(15 \%)$

$1224(15.6)$

$241(26.7 \%)$

$3 \quad 65(42.4 \%)$

Cytology score

0

$3(1.9 \%)$

1

$17(11.1 \%)$

2

$133(86.9 \%)$

For patients with non-pancreatic solid lesions (except lymph nodes)

Histology score

1

2

3

Cytology score

1

2

Patients with lymph nodes

Histology score

0

1

2

3

Cytology score

0

1

2
Table 3. Diagnostic Accuracy Based on Lesion Location

\begin{tabular}{|c|c|}
\hline \multicolumn{2}{|l|}{ All lesions $(n=342)$} \\
\hline Histology, diagnostic accuracy & $254(74.2 \%)$ \\
\hline Cytology, diagnostic accuracy & $294(85.9 \%)$ \\
\hline Combined diagnostic accuracy & $323(94.4 \%)$ \\
\hline \multicolumn{2}{|l|}{ Pancreatic lesions ( $n=153)$} \\
\hline Histology, diagnostic accuracy & $105(68.6 \%)$ \\
\hline Cytology, diagnostic accuracy & $134(87.6 \%)$ \\
\hline Combined diagnostic accuracy & $143(93.5 \%)$ \\
\hline \multicolumn{2}{|l|}{ Lymph nodes $(n=117)$} \\
\hline Histology, diagnostic accuracy & $87(74.4 \%)$ \\
\hline Cytology, diagnostic accuracy & $102(87.2 \%)$ \\
\hline Combined diagnostic accuracy & $111(94.9 \%)$ \\
\hline \multicolumn{2}{|l|}{ Liver lesions $(n=22)$} \\
\hline Histology, diagnostic accuracy & $17(77.2 \%)$ \\
\hline Cytology, diagnostic accuracy & $20(91 \%)$ \\
\hline Combined diagnostic accuracy & $21(95.4 \%)$ \\
\hline \multicolumn{2}{|l|}{ Subepithelial lesions $(n=27)$} \\
\hline Histology, diagnostic accuracy & $27(100 \%)$ \\
\hline Cytology, diagnostic accuracy & $19(70.3 \%)$ \\
\hline Combined diagnostic accuracy & $27(100 \%)$ \\
\hline \multicolumn{2}{|l|}{ Adrenal gland lesions $(n=10)$} \\
\hline Histology, diagnostic accuracy & $7(70 \%)$ \\
\hline Cytology, diagnostic accuracy & $8(80 \%)$ \\
\hline Combined diagnostic accuracy & $9(90 \%)$ \\
\hline \multicolumn{2}{|l|}{ Others $(n=13)$} \\
\hline Histology, diagnostic accuracy & $11(84.6 \%)$ \\
\hline Cytology, diagnostic accuracy & $11(84.6 \%)$ \\
\hline Combined diagnostic accuracy & $12(92.3 \%)$ \\
\hline
\end{tabular}

cytology and histology showing only inflammatory tissue. One patient with autoimmune pancreatitis (AIP) with a pancreatic head mass and EUS-FNB showing IgG-4 negative inflammatory cells was treated for AIP based on serum elevated IgG4 and imaging studies, with resolution of the pancreatic head lesion. One patient with atypical cells from a pancreatic head mass with non-diagnostic cytology was followed for 12 months with serial computed tomography (CT) scans and a stable pancreatic head lesion. In addition, there were 2 patients with post-transplant lymphoproliferative disorders (PTLD) who had initial benign lymph nodes on EUSFNB and resolution of lymphadenopathy with appropriate management of PTLD; 1 patient with ampullary stricture that was revealed to be adenocarcinoma over a 3-month period; 2 patients with ampullary mass on CT but only inflammatory 
Table 4. Neoplastic and Non-Neoplastic Diagnoses

\begin{tabular}{|c|c|}
\hline Neoplastic $(n=265)$ & $n(\%)$ \\
\hline Pancreatic adenocarcinoma & $107(40.3)$ \\
\hline Pancreatic NET & $24(9.1)$ \\
\hline IPMN & $1(0.3)$ \\
\hline GIST & $16(6.3)$ \\
\hline Leiomyoma & $11(4.1)$ \\
\hline Lymphoma & $17(6.4)$ \\
\hline Metastatic lymph nodes & $53(20)$ \\
\hline \multicolumn{2}{|l|}{ Metastasis } \\
\hline Liver metastasis & $22(8.3)$ \\
\hline Primary colon & 6 \\
\hline Primary pancreas & 4 \\
\hline Primary esophageal & 12 \\
\hline Adrenal metastasis & $6(2.2)$ \\
\hline $\begin{array}{l}\text { Primary colon non-small cell lung cancer } \\
\text { (squamous cell cancer) }\end{array}$ & 5 \\
\hline Gastric cancer & 1 \\
\hline Nonfunctional adrenal adenoma & $2(0.7)$ \\
\hline Others & $6(2.2)$ \\
\hline Leiomyosarcoma & 2 \\
\hline Ampullary adenocarcinoma & 1 \\
\hline Rectal adenocarcinoma & 3 \\
\hline Non-neoplastic $(n=58)$ & $n(\%)$ \\
\hline Chronic pancreatitis & $14(24.1)$ \\
\hline AIP & $1(1.7)$ \\
\hline Granulomatous lymphadenitis & $9(15.5)$ \\
\hline Non-necrotizing granulomatous inflammation & 5 \\
\hline Granulomatous inflammation & 4 \\
\hline Goiter nodule & $1(1.7)$ \\
\hline Rectal endometriosis & $1(1.7)$ \\
\hline Intrapancreatic accessory spleen & $1(1.7)$ \\
\hline Lymphadenopathy & $31(53.4)$ \\
\hline
\end{tabular}

AIP, autoimmune pancreatitis; GIST, gastrointestinal stromal tumor; IPMN, intraductal papillary mucinous neoplasm; NET, neuroendocrine tumor.

cells on EUS-FNB who were lost to follow-up; 1 patient with known diffuse large B-cell lymphoma with EUS-FNB from a splenic lesion that was negative for lymphoma; 2 patients with known large B-cell lymphoma with abdominal lymph nodes that were negative for lymphoma on EUS; 1 patient with splenomegaly and an abdominal lymph node biopsy that showed no lymphoma, but whose 12-month follow-up bone marrow biopsy showed Hodgkin's lymphoma; 1 patient who underwent EUS-FNB 3 times for metastatic osteosarcoma with a positron emission tomography-positive pancreatic mass and negative biopsies on all 3 occasions; 1 patient with adenocarcinoma from pleural fluid cytology with negative mediastinal lymph node biopsies; 1 patient with a negative mediastinal lymph node biopsy for metastatic lung cancer who died of lung cancer a few months later; and 1 patient with known lung cancer who underwent EUS-FNB twice with negative adrenal mass biopsies.

\section{DISCUSSION}

EUS-FNA has been the standard for EUS-guided tissue acquisition for more than 2 decades. Although some studies have demonstrated the possibility of obtaining core specimens using conventional FNA needles, ${ }^{15-18}$ diagnosis with EUS-FNA is typically based on cytological samples. In order to overcome this limitation, EUS needles were specifically designed to provide histological tissue samples, and the term "fine-needle biopsy" was coined. However, studies addressing the feasibility of providing histologic samples with these needles and the additive diagnostic value of histological versus cytological assessment are still limited. ${ }^{19,20}$

Studies with first-generation (Quick-Core; Cook Medical Inc., Winston-Salem, NC, USA) and second-generation (Procore; Wilson-Cook Medical Inc.) core biopsy needles have failed to consistently demonstrate the advantage of either needle over a standard EUS-FNA needle in terms of overall diagnostic accuracy. ${ }^{19,21,22}$

Early efforts using the EUS-Trucut needle estimated a diagnostic yield in the range of $52 \%$ to $95 \%$, which was not significantly different compared to conventional FNA. ${ }^{23-25}$ Kandel et al. compared EUS-FNA with EUS-FNB, but their study was limited to a small number of patients in the EUS-FNB group. ${ }^{26}$ The lack of improved diagnostic accuracy with the Trucut needle may be due in part to the fact that a histological sample is not required to reach a diagnosis in most cases ${ }^{14}$ and also to the technical issue of this needle's spring-loaded design with difficult maneuverability that significantly limits its use. In particular, transduodenal biopsies are difficult or impossible using the EUS-Trucut needle. Newer generation core biopsy needles, including the SC needle, have a modified tip design. The needle tip design incorporates 2 sharp points of different lengths, with the second sharp tip on the opposite side of the lumen designed to improve tissue capture. Similar to conventional FNA needles, these needles can be used even in angulated endoscope positions where the EUS-Trucut is not feasible. It can, therefore, be hypothesized that these needles provide tissue samples of higher quality without compromising ease of use. 
Table 5. Non-Diagnostic Lesions

\begin{tabular}{|c|c|c|c|c|c|c|c|}
\hline Patient & $\begin{array}{l}\text { Location of } \\
\text { lesion }\end{array}$ & $\begin{array}{l}\text { Lesion size } \\
\text { (in } \mathbf{~ m m} \text { ) }\end{array}$ & $\begin{array}{l}\text { Access to } \\
\text { lesion }\end{array}$ & $\begin{array}{l}\text { Needle } \\
\text { size }\end{array}$ & $\begin{array}{l}\text { Number } \\
\text { of passes }\end{array}$ & $\begin{array}{c}\text { Final } \\
\text { diagnosis }\end{array}$ & Clinical course \\
\hline 1 & Pancreatic head & $20 \times 6$ & $\begin{array}{l}\text { Trans- } \\
\text { duodenal }\end{array}$ & $22 \mathrm{G}$ & 1 & $\begin{array}{l}\text { Inflammatory } \\
\text { tissue }\end{array}$ & $\begin{array}{l}\text { Patient had a history of chronic pancre- } \\
\text { atitis and had } 2 \text { CT scans with a stable } \\
\text { lesion size over the subsequent } 12 \text { mo }\end{array}$ \\
\hline 2 & Pancreatic head & $24 \times 22$ & Trans-gastric & $22 \mathrm{G}$ & 3 & $\begin{array}{l}\text { Auto-immune } \\
\text { pancreatitis }\end{array}$ & $\begin{array}{l}\text { Patient responded well to treatment with } \\
\text { resolution of the pancreatic lesion }\end{array}$ \\
\hline 3 & Pancreatic head & $18 \times 19$ & $\begin{array}{l}\text { Trans- } \\
\text { duodenal }\end{array}$ & $25 \mathrm{G}$ & 2 & Uncertain & $\begin{array}{l}\text { Serial CT scan showed a stable lesion size } \\
\text { over a } 12 \text {-mo period }\end{array}$ \\
\hline 4 & $\begin{array}{l}\text { Mediastinal } \\
\text { lymph nodes }\end{array}$ & $14 \times 12$ & $\begin{array}{l}\text { Trans- } \\
\text { esophageal }\end{array}$ & $25 \mathrm{G}$ & 1 & Uncertain & Patient died from known lung cancer \\
\hline 5 & $\begin{array}{l}\text { Mediastinal } \\
\text { lymph nodes }\end{array}$ & $48 \times 22$ & $\begin{array}{c}\text { Trans- } \\
\text { esophageal }\end{array}$ & $25 \mathrm{G}$ & 3 & Benign tissue & $\begin{array}{l}\text { Pleural cytology was positive for adeno- } \\
\text { carcinoma }\end{array}$ \\
\hline 6 & Pancreatic head & $30 \times 23$ & $\begin{array}{l}\text { Trans- } \\
\text { duodenal }\end{array}$ & $22 \mathrm{G}$ & 5 & $\begin{array}{l}\text { Atypical cells } \\
\text { seen }\end{array}$ & $\begin{array}{l}\text { PET-positive pancreatic head mass in a } \\
\text { patient with known metastatic osteosar- } \\
\text { coma }\end{array}$ \\
\hline 7 & Pancreatic head & $30 \times 24$ & $\begin{array}{l}\text { Trans- } \\
\text { duodenal }\end{array}$ & $22 \mathrm{G}$ & 6 & $\begin{array}{l}\text { Atypical cells } \\
\text { seen }\end{array}$ & $\begin{array}{l}\text { PET-positive pancreatic head mass in a } \\
\text { patient with known metastatic osteosar- } \\
\text { coma }\end{array}$ \\
\hline 8 & Pancreatic head & $30 \times 24$ & $\begin{array}{l}\text { Trans- } \\
\text { duodenal }\end{array}$ & $22 \mathrm{G}$ & 4 & $\begin{array}{l}\text { Atypical cells } \\
\text { seen }\end{array}$ & $\begin{array}{l}\text { PET-positive pancreatic head mass in a } \\
\text { patient with known metastatic osteosar- } \\
\text { coma }\end{array}$ \\
\hline 9 & $\begin{array}{l}\text { Abdominal } \\
\text { lymph nodes }\end{array}$ & $31 \times 14$ & $\begin{array}{l}\text { Trans- } \\
\text { duodenal }\end{array}$ & $22 \mathrm{G}$ & 1 & $\begin{array}{l}\text { Benign } \\
\text { lymph nodes }\end{array}$ & $\begin{array}{l}\text { Patient had known large B-cell lympho- } \\
\text { ma. Reduced PET uptake post-treat- } \\
\text { ment cycle }\end{array}$ \\
\hline 10 & $\begin{array}{l}\text { Abdominal } \\
\text { lymph nodes }\end{array}$ & $31 \times 14$ & $\begin{array}{l}\text { Trans- } \\
\text { duodenal }\end{array}$ & $22 \mathrm{G}$ & 2 & $\begin{array}{l}\text { Benign } \\
\text { lymph nodes }\end{array}$ & $\begin{array}{l}\text { Patient with known large B-cell lympho- } \\
\text { ma. Reduced PET uptake post-treat- } \\
\text { ment cycle }\end{array}$ \\
\hline 11 & $\begin{array}{l}\text { Abdominal } \\
\text { lymph nodes }\end{array}$ & $27 \times 16$ & Trans-gastric & $22 \mathrm{G}$ & 4 & $\begin{array}{c}\text { Possible } \\
\text { lymphoma }\end{array}$ & $\begin{array}{l}\text { Bone marrow biopsy at } 12 \text { mo showed } \\
\text { Hodgkin's lymphoma }\end{array}$ \\
\hline 12 & Spleen & $14 \times 11$ & Trans-gastric & $22 \mathrm{G}$ & 3 & Splenic tissue & $\begin{array}{l}\text { Patient with known large B-cell lympho- } \\
\text { ma. Stable size at follow-up CT imaging }\end{array}$ \\
\hline 13 & $\begin{array}{l}\text { Abdominal } \\
\text { lymph nodes }\end{array}$ & $15 \times 12$ & $\begin{array}{l}\text { Trans- } \\
\text { duodenal }\end{array}$ & $25 \mathrm{G}$ & 6 & PTLD & $\begin{array}{l}\text { Reduction in lymph node size after ap- } \\
\text { propriate PTLD management }\end{array}$ \\
\hline 14 & $\begin{array}{l}\text { Abdominal } \\
\text { lymph nodes }\end{array}$ & $45 \times 40$ & $\begin{array}{l}\text { Trans- } \\
\text { duodenal }\end{array}$ & $22 \mathrm{G}$ & 7 & PTLD & $\begin{array}{l}\text { Reduction in lymph node size after ap- } \\
\text { propriate PTLD management }\end{array}$ \\
\hline 15 & Ampulla & $19 \times 10$ & $\begin{array}{l}\text { Trans- } \\
\text { duodenal }\end{array}$ & $25 \mathrm{G}$ & 3 & $\begin{array}{l}\text { Atypical cells } \\
\text { seen }\end{array}$ & Ampullary adenocarcinoma at $3 \mathrm{mo}$ \\
\hline 16 & Ampulla & $20 \times 15$ & $\begin{array}{l}\text { Trans- } \\
\text { duodenal }\end{array}$ & $25 \mathrm{G}$ & 3 & $\begin{array}{l}\text { Atypical cells } \\
\text { seen }\end{array}$ & Lost to follow-up \\
\hline 17 & Ampulla & $12 \times 10$ & $\begin{array}{l}\text { Trans- } \\
\text { duodenal }\end{array}$ & $22 \mathrm{G}$ & 4 & $\begin{array}{l}\text { inflammatory } \\
\text { cells }\end{array}$ & Lost to follow-up \\
\hline 18 & Adrenal & $12 \times 11$ & Trans-gastric & $25 \mathrm{G}$ & 3 & $\begin{array}{l}\text { Normal } \\
\text { adrenal tissue }\end{array}$ & $\begin{array}{l}\text { Patient with lung cancer, adrenal lesions } \\
\text { remained stable on subsequent } 2 \mathrm{CT} \\
\text { scans over } 6 \text { mo }\end{array}$ \\
\hline 19 & Adrenal & $12 \times 11$ & Trans-gastric & $22 \mathrm{G}$ & 2 & $\begin{array}{c}\text { Normal } \\
\text { adrenal tissue }\end{array}$ & $\begin{array}{l}\text { Patient with lung cancer, adrenal lesions } \\
\text { remained stable on subsequent } 2 \mathrm{CT} \\
\text { scans over } 6 \text { mo }\end{array}$ \\
\hline
\end{tabular}

CT, computed tomography; PET, positron emission tomography; PTLD, post-transplant lymphoproliferative disorders. 
Earlier studies have focused heavily on solid pancreatic lesions to evaluate the diagnostic yields of the SC FNB needle against the standard FNA needle. ${ }^{27-30}$ In this study, we evaluated the yield of histologic tissue samples and the diagnostic accuracy of EUS-guided fine needle biopsy in patients with solid lesions located in the GI tract and surrounding organs. To the best of our knowledge, our retrospective cohort study is the largest study to date to evaluate the performance of the SC FNB needle for a wide array of solid lesions and not only solid pancreatic lesions. In our series, we achieved a very high diagnostic accuracy of $93.5 \%$ when combining cytological (touch imprint cytology and smears) and histological (cell-block and tissue in formalin) assessment. The yield of the histological samples alone was 77\% (264 patients with histology scores of 2 or more) (Table 2). This is lower than the histology yield of $88 \%$ (109/124 lesions) in the study by DiMaio et al. using the same needle. ${ }^{28}$ The higher yield in the DiMaio et al. study was likely due to the difference in study design. ${ }^{28}$ In their study, a total of 250 lesions underwent EUS-tissue acquisition, but only 124 samples were sent for histological analysis. Furthermore, in their study, $65 \%$ of the lesions were pancreatic lesions (81 of 124 lesions that underwent EUS-FNB). In comparison, pancreatic lesions accounted for only $44 \%$ (153 of 342) of the biopsy targets in our series, which may explain the difference in histologic yield. Furthermore, Tables 2 and 3 show the histological and cytological sample adequacy and diagnostic accuracy using the SC needle for individual lesion locations, respectively.

A recent multicenter retrospective trial showed no significant difference between the diagnostic accuracy of FNA versus FNB with the SC needle (96.5\% vs. $92 \%){ }^{27}$ However, there are some key points to note from that retrospective study. First, the study only included patients with solid pancreatic lesions and obtaining a tissue core may not be paramount in the diagnosis of pancreatic adenocarcinoma, in contrast to lesions such as stromal tumor, lymphoma, and benign lymphadenopathy. Second, the negative predictive value of FNB with the SC needle was $97.5 \%$ compared to only $53.7 \%$ for FNA with a conventional needle $(p<0.01){ }^{27}$ It has been previously suggested that histological samples have a distinct advantage over cytological samples in the diagnosis of benign lesions. The absence of malignant cells on cytology may not be sufficient to label a lesion as benign, and false negative cytology results are common. ${ }^{31,32}$ In this context, a core biopsy either facilitates the diagnosis of a specific benign diagnosis, for example, granulomatous lymphadenitis, or the larger sample provides greater confidence in the absence of cancer in non-specific benign lesions such as reactive lymph nodes. In our series, a diagnosis of granulomatous lymphadenitis was made in 9 patients based on cytological and histological assessment.
The cytological material alone helped diagnosis in 2 patients, the histological material alone was helpful in 3 patients, and both the cytological and histological material helped in establishing a diagnosis in 4 patients. This lends further evidence to the hypothesis that histological assessment is particularly helpful in determining the etiology of benign lymphadenitis. A recently published RCT showed not only a superior histological yield but also increased diagnostic accuracy for FNB with a 20-gauge Procore needle compared to FNA with a 25-gauge FNA needle. ${ }^{33}$ These results are in line with the excellent histological yields and overall diagnostic accuracy in our study.

Our study was not designed to compare FNA using a conventional needle with FNB. Even the cytological information in our series was typically obtained through touch preps derived from tissue cores. The cytological assessment was more frequently diagnostic than the histological assessment alone, which highlights the fact the histological component is not crucial to achieve a diagnosis in most cases. It may, however, facilitate accessory stains and provide a more specific diagnosis than cytology alone. Further, there is growing interest in gene-guided therapy for malignancies, which requires core biopsy samples for molecular and genetic testing. ${ }^{34,35}$

We used ROSE in almost all our cases. Although we did not formally investigate this, we believe that the presence of a visible tissue core is a strong indicator of an adequate sample. Thus, FNB may reduce dependence on ROSE, which would make EUS a more cost-effective procedure and confer a crucial benefit at institutions lacking an on-site cytology service.

A remarkable finding in our study is that samples were obtained with a median of only 2 needle passes. This is lower than the number of previously reported passes with conventional $\mathrm{FNA}^{36}$ and supports the observation of previous studies that fewer needle passes were required with FNB than with FNA. ${ }^{27,36,37}$

Our study has several strengths. This is the largest study to date to examine the performance of EUS-FNB with the SC needle in an unselected population with solid lesions. We examined the outcomes of both the cytological and histological components of the tissue analysis. We focused on sample quality as our primary endpoint because the diagnostic accuracy rate may not reflect important nuances including the additive diagnostic value of high-quality samples that facilitate accessory staining and may provide a more specific diagnosis.

The main limitation of the study is its retrospective design. Additionally, we did not compare FNB with conventional FNA. We only analyzed the impact of the cytological and the histological components on the overall diagnosis. Furthermore, we used ROSE in almost all cases. However, further studies are necessary to address whether our findings can 
indeed be generalized to settings where ROSE is not available. Based on the excellent adequacy of our biopsy samples, we contend that FNB with the SC needle may reduce the need for ROSE.

EUS-FNB with the SC needle provides histologic tissue cores in the majority of cases and achieves excellent diagnostic accuracy with few needle passes. Histologic samples in combination with cytology increase the ability to obtain a specific diagnosis. Moreover, histology facilitates ancillary diagnostic tests and may gain importance with individualized tumor treatment based on the genetic make-up.

Conflicts of Interest

The authors have no financial conflicts of interest.

Author Contributions

Conceptualization: Munish Ashat, Chris Jensen, Rami El-Abiad, Henning Gerke

Data curation: MA, Sarika Gupta, CJ, REA

Formal analysis: SG, Arvind R. Murali

Methodology: Kaartik Soota, Jagpal S. Klair, REA, HG

Supervision: ARM, Randhir Jesudoss

Writing-original draft: MA, ARM, REA, HG

Writing-review\&editing: MA, KS, JSK, REA, HG

\section{REFERENCES}

1. Yoshinaga S, Suzuki H, Oda I, Saito Y. Role of endoscopic ultrasound-guided fine needle aspiration (EUS-FNA) for diagnosis of solid pancreatic masses. Dig Endosc 2011;23 Suppl 1:29-33.

2. Hewitt MJ, McPhail MJ, Possamai L, Dhar A, Vlavianos P, Monahan KJ. EUS-guided FNA for diagnosis of solid pancreatic neoplasms: a meta-analysis. Gastrointest Endosc 2012;75:319-331.

3. Gleeson FC, Kipp BR, Caudill JL, et al. False positive endoscopic ultrasound fine needle aspiration cytology: incidence and risk factors. Gut 2010;59:586-593.

4. Ieni A, Todaro P, Crino SF, Barresi V, Tuccari G. Endoscopic ultrasound-guided fine-needle aspiration cytology in pancreaticobiliary carcinomas: diagnostic efficacy of cell-block immunocytochemistry. Hepatobiliary Pancreat Dis Int 2015;14:305-312.

5. Yan BM, Pai RK, Van Dam J. Diagnosis of pancreatic gastrointestinal stromal tumor by EUS guided FNA. JOP 2008;9:192-196.

6. Levy MJ. Endoscopic ultrasound-guided trucut biopsy of the pancreas: prospects and problems. Pancreatology 2007;7:163-166.

7. Klapman JB, Logrono R, Dye CE, Waxman I. Clinical impact of onsite cytopathology interpretation on endoscopic ultrasound-guided fine needle aspiration. Am J Gastroenterol 2003;98:1289-1294.

8. Sandhu DS, Holm AN, El-Abiad R, Rysgaard C, Jensen C, Gerke H. Endoscopic ultrasound with tissue sampling is accurate in the diagnosis and subclassification of gastrointestinal spindle cell neoplasms. Endosc Ultrasound 2017;6:174-180.

9. Hedenström P, Marschall HU, Nilsson B, et al. High clinical impact and diagnostic accuracy of EUS-guided biopsy sampling of subepithelial lesions: a prospective, comparative study. Surg Endosc 2018;32:1304-1313.

10. Varadarajulu S, Fraig M, Schmulewitz N, et al. Comparison of EUS-guided 19-gauge Trucut needle biopsy with EUS-guided fine-needle aspiration. Endoscopy 2004;36:397-401.

11. Cohen MB, Egerter DP, Holly EA, Ahn DK, Miller TR. Pancreatic ade- nocarcinoma: regression analysis to identify improved cytologic criteria. Diagn Cytopathol 1991;7:341-345.

12. Schwartz DA, Unni KK, Levy MJ, Clain JE, Wiersema MJ. The rate of false-positive results with EUS-guided fine-needle aspiration. Gastrointest Endosc 2002;56:868-872.

13. Siddiqui AA, Kowalski TE, Shahid H, et al. False-positive EUS-guided FNA cytology for solid pancreatic lesions. Gastrointest Endosc 2011;74:535-540.

14. Gerke H, Rizk MK, Vanderheyden AD, Jensen CS. Randomized study comparing endoscopic ultrasound-guided Trucut biopsy and fine needle aspiration with high suction. Cytopathology 2010;21:44-51.

15. Voss M, Hammel P, Molas G, et al. Value of endoscopic ultrasound guided fine needle aspiration biopsy in the diagnosis of solid pancreatic masses. Gut 2000;46:244-249.

16. Larghi A, Noffsinger A, Dye CE, Hart J, Waxman I. EUS-guided fine needle tissue acquisition by using high negative pressure suction for the evaluation of solid masses: a pilot study. Gastrointest Endosc 2005;62:768-774.

17. Larghi A, Verna EC, Ricci R, et al. EUS-guided fine-needle tissue acquisition by using a 19-gauge needle in a selected patient population: a prospective study. Gastrointest Endosc 2011;74:504-510.

18. Varadarajulu S, Bang JY, Hebert-Magee S. Assessment of the technical performance of the flexible 19-gauge EUS-FNA needle. Gastrointest Endosc 2012;76:336-343.

19. Bang JY, Hawes R, Varadarajulu S. A meta-analysis comparing ProCore and standard fine-needle aspiration needles for endoscopic ultrasound-guided tissue acquisition. Endoscopy 2016;48:339-349.

20. Polkowski M, Jenssen C, Kaye P, et al. Technical aspects of endoscopic ultrasound (EUS)-guided sampling in gastroenterology: European Society of Gastrointestinal Endoscopy (ESGE) technical guideline - March 2017. Endoscopy 2017;49:989-1006.

21. Sakamoto H, Kitano M, Komaki T, et al. Prospective comparative study of the EUS guided 25-gauge FNA needle with the 19-gauge Trucut needle and 22-gauge FNA needle in patients with solid pancreatic masses. J Gastroenterol Hepatol 2009;24:384-390.

22. Wittmann J, Kocjan G, Sgouros SN, Deheragoda M, Pereira SP. Endoscopic ultrasound-guided tissue sampling by combined fine needle aspiration and trucut needle biopsy: a prospective study. Cytopathology 2006;17:27-33.

23. Levy MJ, Jondal ML, Clain J, Wiersema MJ. Preliminary experience with an EUS-guided trucut biopsy needle compared with EUS-guided FNA. Gastrointest Endosc 2003;57:101-106.

24. Cho CM, Al-Haddad M, Leblanc JK, Sherman S, McHenry L, Dewitt J. Rescue endoscopic ultrasound (EUS)-guided Trucut biopsy following suboptimal EUS-guided fine needle aspiration for mediastinal lesions. Gut Liver 2013;7:150-156.

25. Ginès A, Wiersema MJ, Clain JE, Pochron NL, Rajan E, Levy MJ. Prospective study of a Trucut needle for performing EUS-guided biopsy with EUS-guided FNA rescue. Gastrointest Endosc 2005;62:597-601.

26. Kandel P, Tranesh G, Nassar A, et al. EUS-guided fine needle biopsy sampling using a novel fork-tip needle: a case-control study. Gastrointest Endosc 2016;84:1034-1039.

27. Naveed M, Siddiqui AA, Kowalski TE, et al. A Multicenter comparative trial of a novel EUS-guided core biopsy needle (SharkCore ${ }^{\mathrm{rx}}$ ) with the 22-gauge needle in patients with solid pancreatic mass lesions. Endosc Ultrasound 2018;7:34-40.

28. DiMaio CJ, Kolb JM, Benias PC, et al. Initial experience with a novel EUS-guided core biopsy needle (SharkCore): results of a large North American multicenter study. Endosc Int Open 2016;4:E974-E979.

29. Witt BL, Factor RE, Chadwick BE, Caron J, Siddiqui AA, Adler DG. Evaluation of the SharkCore ${ }^{\circ}$ needle for EUS-guided core biopsy of pancreatic neuroendocrine tumors. Endosc Ultrasound 2018;7:323-328.

30. El Chafic AH, Loren D, Siddiqui A, Mounzer R, Cosgrove N, Kowalski T. Comparison of FNA and fine-needle biopsy for EUS-guided sampling of suspected GI stromal tumors. Gastrointest Endosc 2017;86:510-515. 
31. Eloubeidi MA, Varadarajulu S, Desai S, et al. A prospective evaluation of an algorithm incorporating routine preoperative endoscopic ultrasound-guided fine needle aspiration in suspected pancreatic cancer. J Gastrointest Surg 2007;11:813-819.

32. Turner BG, Cizginer S, Agarwal D, Yang J, Pitman MB, Brugge WR. Diagnosis of pancreatic neoplasia with EUS and FNA: a report of accuracy. Gastrointest Endosc 2010;71:91-98.

33. van Riet PA, Larghi A, Attili F, et al. A multicenter randomized trial comparing a 25-gauge EUS fine-needle aspiration device with a 20-gauge EUS fine-needle biopsy device. Gastrointest Endosc 2019;89:329-339.

34. Itoi $\mathrm{T}$, Takei $\mathrm{K}$, Sofuni $\mathrm{A}$, et al. Immunohistochemical analysis of $\mathrm{p} 53$ and MIB-1 in tissue specimens obtained from endoscopic ultrasonog- raphy-guided fine needle aspiration biopsy for the diagnosis of solid pancreatic masses. Oncol Rep 2005;13:229-234.

35. Brais RJ, Davies SE, O’Donovan M, et al. Direct histological processing of EUS biopsies enables rapid molecular biomarker analysis for interventional pancreatic cancer trials. Pancreatology 2012;12:8-15.

36. Mukai S, Itoi T, Yamaguchi H, et al. A retrospective histological comparison of EUS-guided fine-needle biopsy using a novel franseen needle and a conventional end-cut type needle. Endosc Ultrasound 2019;8:5057.

37. Li H, Li W, Zhou QY, Fan B. Fine needle biopsy is superior to fine needle aspiration in endoscopic ultrasound guided sampling of pancreatic masses: a meta-analysis of randomized controlled trials. Medicine (Baltimore) 2018;97:e0207. 